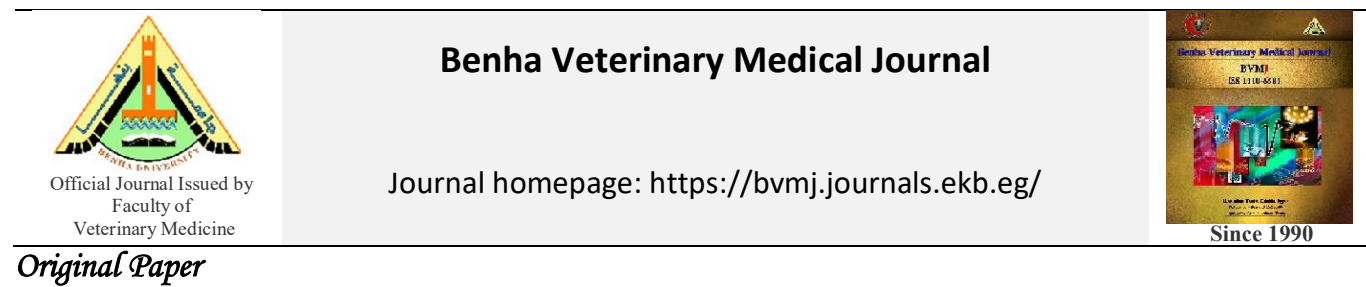

\title{
Isolation of Salmonella species in freshly dead rabbit samples in Qalubiya Governorate,
} Egypt

Ashraf A. Abd El Tawab ${ }^{1}$, Fatma I. El-Hofy ${ }^{1}$, Amany, O. Selim ${ }^{1}$, Lamia, A. Elmeniawy

${ }^{\prime}$ Department of Bacteriology, Immunology and Mycology, Faculty of Veterinary Medicine, Benha University, Egypt

${ }^{2}$ Bacteriology Department, Animal Health Research Institute, ARC, Egypt.

\section{ARTICLE INFO}

\begin{tabular}{l}
\hline Keywords \\
Salmonella species \\
serological identification \\
PCR \\
antimicrobial \\
susceptibility
\end{tabular}

Received 24/03/2021

Accepted 31/03/2021

Available On-Line

01/07/2021

\begin{abstract}
This study was carried to examine one hundred and sixty-three different freshly dead rabbits' corpses collected from different husbandries of rabbit rearing located in Qalubiya governorate, suffered from mortalities along the period from January 2020 to March 2021. From each collected corpse sample, five internal organs represented by liver, kidney, spleen, lung and intestine were collected for bacteriological investigation for the presence of Salmonella species; after which serological identification of Salmonella isolates was performed then sensitivity test was applied to detect resistance to some antibiotics groups Resistance genes $(A a d B, q n r S$ and TetA(A))are detected . Results of bacteriological examinations revealed that isolation of thirty-one different Salmonella species, where isolated from liver 7, kidney 5, spleen 10, lung 3, and intestine 6 isolates with incidence of 22.5, 16.1,32.3, 9.6, and 19.35\% respectively. Moreover, serological identification clarified that out of thirty-one isolates, $9(29.03 \%)$ strains were S. Arizonae, 5(16.12\%) strains were S. Kentucky, $7(22.58 \%)$ strains were S. Enteritidis, and 8(25.80\%) strains were S. Typhimurium, and 2(6.45\%) strain was S. Banana. Referring to the obtained results, Salmonella was regarded as significant bacteria responsible for several morbidity and mortalities cases in rabbit farms. Antimicrobial susceptibility was applied on Salmonella strains and referred that salmonella have high resistance to streptomycin, tetracycline and quinolones group. Moreover, resistance genes (aadB, qnrs, and tetA(A) were also detecting using PCR.
\end{abstract}

\section{INTRODUCTION}

Salmonellae are classified into two main species, Salmonella enterica and Salmonella bongori, where $S$. Enterica species is further divided into six subspecies (Ryan et al., 2017), that include over 2,600 serotypes (Gal-Mor et al., 2014).

Salmonella species characterized microscopically by Gram negative reaction, encapsulated, non-sporulated, aerobic and/or facultative anaerobes, short bacilli, motile bacterium belonging to Enterobacteriaceae family (Mondal et al., 2008); which serologically typed by mixing pure bacterial colony with antibodies for a particular antigen (O- and $\mathrm{H}-$ antigens) (Okoro et al., 2012). Serotyping can assist identify the source of contamination by matching serotypes in people with serotypes in the suspected source of infection (CDC, 2018).

Although salmonellosis is uncommon disease in rabbits, it can occur in association with contaminated food or water (Zahraei et al., 2010). Rabbit salmonellosis characterized by significant weight loss, lethargy, lack of appetite, and unresponsive to stimuli with high mortality rates (Panda et $a l ., 2015)$. So, it has been recorded as significant disease in rabbits, with economic losses and public health importance as infected rabbits can shedding Salmonella even apparently healthy, therefore, it can infect human (Saco et al., 2012; CDC, 2015).

\footnotetext{
* Corresponding author: lamiaaelmenyawy@gmail.com
}

Therefore, the study aimed at isolation and identification of Salmonella species in internal organs of freshly dead rabbits and antimicrobial susceptibility and detection of resistance genes (a adB, qnrs, and tetA(A) using PCR.

\section{MATERIAL AND METHODS}

\subsection{Collection of samples:}

One hundred and sixty-three random freshly dead rabbits of previously notified suffering from signs if diarrhea, lethargy, and weight loss, were collected from 100 rabbits located in Qalubiya Governorate. Corpses were transferred to the laboratory, in which PM examination and internal organs collection were done. Liver, kidney, spleen, lung, and intestine samples were collected from each corpse aseptically, and kept in sterile plastic bags until examination. Isolation and identification of salmonellae were performed following Markey et al. (2013), and ISO (2017).

The surface of each examined organ was seared by hot spatula, small pieces of them were taken under aseptic condition and putted in sterile Stomacher bag with $45 \mathrm{ml}$ sterile buffered peptone water, and incubated at $37 \pm 1^{\circ} \mathrm{C}$ for $18 \pm 2$ hours, then transferred to Rappaport Vassilidis broth (RV broth) and incubated at $43 \pm 1^{\circ} \mathrm{C} / 24 \mathrm{hr}$. loopful of the incubated broth was plated on selective XLD agar (Oxoid Co.) and SS agar (Oxoid Co.), and incubated at 
$37 \pm 1^{\circ} \mathrm{C} / 24 \mathrm{hrs}$, plates were examined for suspected Salmonella colonies which then isolated for confirmation. The suspected colonies were sub-cultured into nutrient agar plate and incubated at $37 \pm 1^{\circ} \mathrm{C}$ for 24 hours. Then, the purified colonies were identified morphologically by Gram stain then biochemically on TSI agar, Urea agar, and LLysine decarboxylation media, and serologically using commercial polyvalent somatic (O-) and flagellar (H-) salmonella antisera (Sifin).

Typical Salmonella colonies grown on XLD agar medium had a pink color with black center while is straw colored with black center on SS agar.

2.2. Detection of antibiotic resistance genes:

A sterile cotton swab of bacterial suspension was streaked onto Mueller-Hinton agar (MHA) plates (Biotec, UK). Then, antimicrobial discs with the following drug contents: Enrofloxacin $(5 \mu \mathrm{g})$, Gentamicin $(30 \mu \mathrm{g})$, Co-Trimoxazole $(25 \mu \mathrm{g})$, Amikacin $(30 \mu \mathrm{g})$, Norfloxacin $(10 \mu \mathrm{g})$, Doxycycline $(30 \mu \mathrm{g})$, Levofloxacin $(5 \mu \mathrm{g})$, Tetracycline (30 $\mu \mathrm{g})$, Azithromycin $(15 \mu \mathrm{g})$, were placed on the plates. The plates were incubated at $37^{\circ} \mathrm{C}$ for $16-18 \mathrm{~h}$.

2.3. Serological identification of salmonella isolates:

Confirmed Salmonella isolates have been uncovered to serological identity consistent with White Kauffman le Minor Scheme (Kauffman, 1974) for determination of flagellar $(\mathrm{H})$ and somatic $(\mathrm{O})$ antigens.

2.4. Confirmation of resistance genes (aadB, qnrs, and tetA(A)) in Salmonella using PCR:

The DNA was extracted according to QIAamp DNA mini kit instructions and PCR master mix was prepared according to Emerald Amp GT PCR (Takara) Code No. RR310A kit The sequence of the used primers (Metabion Germany) and amplification conditions were listed in table (1). Separation of PCR products were done on $1.5 \%$ agarose gel (Sambrook et al., 1989) in $100 \mathrm{ml} \mathrm{TBE}$ buffer at $1-5 \mathrm{~V} / \mathrm{cm}$, twenty $\mu \mathrm{l}$ of each uniplex PCR product and negative and positive controls were loaded to the gel. The power supply was $1-5 \mathrm{~V} / \mathrm{cm}$ of the tank length.
Gene's ruler 100 bp DNA ladder (cat. no. SM0243) supplied from Fermentas with Number of bands: 10 and Size range: $100-1000 \mathrm{bp}$

\section{RESULTS}

3.1. Identification and isolation of Salmonella isolates:

Out of 163 examined rabbit, 11 (6.7\%) corpses had Salmonella species; from which 7, 5, 10, 3, and 6 isolates with incidence of $22.5,16.1,32.2,9.6$, and $19.35 \%$ were isolated from liver, kidney, spleen, lung, and intestine samples, respectively as recorded in Table (2).

3.2. Serological identification of Salmonella isolates:

Table (3) revealed that moreover, out of thirty-one isolates, $9(29.03 \%)$ strains were $S$. Arizonae, $5(16.12 \%)$ strains were S. Kentucky, 7(22.58\%) strains were S. Enteritidis, and $8(25.80 \%)$ strains were $S$. Typhimurium, and $2(6.45 \%)$ strain was $S$. Banana.

3.3. Results of in vitro antimicrobial susceptibility:

As in Table (4), out of thirty-one Salmonella isolates, ten random isolates were tested for antibiotic sensitivity for (Enrofloxacin, Gentamicin, Co-trimoxazole, Amikacin, Norfloxacin, Doxycycline, Levofloxacin, Tetracycline, and Azithromycin); and found that $(60 \%)$ resistant to norfloxacin, levofloxacin, and tetracycline; $(50 \%)$ resistant to enrofloxacin and gentamicin; while most of them were sensitive to co-trimoxazole, amikacin, doxycycline, and azithromycin.

3.4. PCR results for Salmonella antibiotic resistance genes: Different five strains of Salmonella were tested for presence or absences of resistance genes mainly resistance to gentamicin $(a \mathrm{adB})$, quinolones ( $q n r s)$, and tetracycline (tetA (A) were determined by PCR and the set of primers used for each gene.

Results revealed detection of all $a a d B$, qnrs, and tetA(A) genes in all the five examined Salmonella isolates as shown in the electrophoresis figures (1 to 3 ), respectively.

Table 1 The sequence of the used primer and amplification conditions.

\begin{tabular}{|c|c|c|c|c|c|c|c|c|c|}
\hline \multirow{2}{*}{ 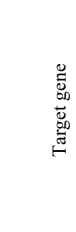 } & & \multirow[b]{2}{*}{$\begin{array}{l}\text { Primers sequences } \\
5^{\prime}-3^{\prime}\end{array}$} & \multirow{2}{*}{ 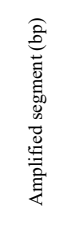 } & \multirow{2}{*}{ 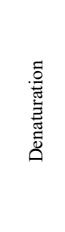 } & \multicolumn{3}{|c|}{$\begin{array}{l}\text { Amplification } \\
\text { (35 cycles) }\end{array}$} & \multirow{2}{*}{ 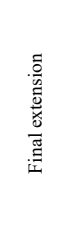 } & \multirow[b]{2}{*}{ Ref. } \\
\hline & & & & & 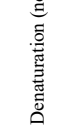 & $\begin{array}{l}\stackrel{0 D}{\Xi} \\
\text { 导 } \\
\text { 志 }\end{array}$ & 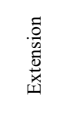 & & \\
\hline \multirow{2}{*}{$\operatorname{aad} B$} & $\mathrm{~F}$ & GAGCGAAATCTGCCGCTCTGG & \multirow{2}{*}{$319 \mathrm{bp}$} & \multirow{2}{*}{$\begin{array}{l}94^{\circ} \mathrm{C} \\
5 \mathrm{~min} .\end{array}$} & \multirow{2}{*}{$\begin{array}{c}94^{\circ} \mathrm{C} \\
30 \mathrm{sec} .\end{array}$} & \multirow{2}{*}{$\begin{array}{c}50^{\circ} \mathrm{C} \\
40 \mathrm{sec} .\end{array}$} & \multirow{2}{*}{$\begin{array}{l}72^{\circ} \mathrm{C} \\
45 \mathrm{sec} .\end{array}$} & \multirow{2}{*}{$\begin{array}{c}72^{\circ} \mathrm{C} \\
10 \mathrm{~min}\end{array}$} & \multirow{2}{*}{ Frana et al., 2001} \\
\hline & $\mathrm{R}$ & CTGTTACAACGGACTGGCCGC & & & & & & & \\
\hline \multirow{2}{*}{ qnrs } & $\mathrm{F}$ & ACGACATTCGTCAACTGCAA & \multirow{2}{*}{$417 \mathrm{bp}$} & \multirow{2}{*}{$\begin{array}{l}94^{\circ} \mathrm{C} \\
5 \mathrm{~min} .\end{array}$} & \multirow{2}{*}{$\begin{array}{c}94^{\circ} \mathrm{C} \\
30 \mathrm{sec} .\end{array}$} & \multirow{2}{*}{$\begin{array}{c}55^{\circ} \mathrm{C} \\
40 \mathrm{sec} .\end{array}$} & \multirow{2}{*}{$\begin{array}{l}72^{\circ} \mathrm{C} \\
45 \mathrm{sec} .\end{array}$} & \multirow{2}{*}{$\begin{array}{c}72^{\circ} \mathrm{C} \\
10 \mathrm{~min}\end{array}$} & \multirow{2}{*}{ Robicsek et al., 2006} \\
\hline & $\mathrm{R}$ & TAAATTGGCACCCTGTAGGC & & & & & & & \\
\hline \multirow{2}{*}{$\operatorname{tet} A(A)$} & $\mathrm{F}$ & GGTTCACTCGAACGACGTCA & \multirow{2}{*}{576 bp } & \multirow{2}{*}{$\begin{array}{l}94^{\circ} \mathrm{C} \\
5 \mathrm{~min} .\end{array}$} & \multirow{2}{*}{$\begin{array}{c}94^{\circ} \mathrm{C} \\
30 \mathrm{sec}\end{array}$} & \multirow{2}{*}{$\begin{array}{c}55^{\circ} \mathrm{C} \\
40 \mathrm{sec} .\end{array}$} & \multirow{2}{*}{$\begin{array}{c}72^{\circ} \mathrm{C} \\
45 \mathrm{sec} .\end{array}$} & \multirow{2}{*}{$\begin{array}{c}72^{\circ} \mathrm{C} \\
10 \mathrm{~min} .\end{array}$} & \multirow{2}{*}{ Randall etal. 2004} \\
\hline & $\mathrm{R}$ & CTGTCCGACAAGTTGCATGA & & & & & & & \\
\hline
\end{tabular}

Table 2 Incidence of Salmonella species in the examined samples

\begin{tabular}{|c|c|c|c|c|c|c|c|c|c|c|c|c|c|}
\hline \multirow{2}{*}{ Total rabbit corpses } & \multirow{2}{*}{\multicolumn{2}{|c|}{ Positive samples }} & \multirow{2}{*}{ Total number of isolates } & \multicolumn{10}{|c|}{ Internal organs } \\
\hline & & & & \multicolumn{2}{|c|}{ Liver } & \multicolumn{2}{|c|}{ Kidney } & \multicolumn{2}{|c|}{ Spleen } & \multicolumn{2}{|c|}{ Lung } & \multicolumn{2}{|c|}{ Intestine } \\
\hline \multirow{2}{*}{163} & No. & $\% *$ & \multirow{2}{*}{31} & No. & $\% * *$ & No. & $\% * *$ & No. & $\% * *$ & No. & $\% * *$ & No. & $\% * *$ \\
\hline & 11 & 6.7 & & 7 & 22.5 & 5 & 16.1 & 10 & 32.2 & 3 & 9.6 & 6 & 19.35 \\
\hline
\end{tabular}

$\% *$ : Incidence in relation to total number of the examined rabbit corpses (163).

$\% * *$ : Incidence in relation to total number of the isolates (31). 
Table 3 Serological identification of Salmonella isolates

\begin{tabular}{|c|c|c|c|c|}
\hline \multirow[t]{2}{*}{ Serotypes } & \multicolumn{4}{|c|}{ Antigenic structure } \\
\hline & z̆ & $\stackrel{\circ}{*}$ & $\mathrm{O}$ & $\mathrm{H}$ \\
\hline S. Enteritidis & 7 & 22.58 & $1,9,12$ & $\mathrm{~g}, \mathrm{~m}:-$ \\
\hline S. Kentuckey & 5 & 16.12 & 8,20 & $\mathrm{i}: \mathrm{Z6}$ \\
\hline S. Arizonae & 9 & 29.03 & 18: & $\mathrm{Z}_{4}, \mathrm{Z}_{32}:-$ \\
\hline S. Typhimurium & 8 & 25.80 & $1,4,5,12$ & $\mathrm{i}: 1,2$ \\
\hline S. Banana & 2 & 6.45 & $1,4,5,12$ & $\mathrm{~m}, \mathrm{t}: 1,5$ \\
\hline
\end{tabular}

Table 4 Antimicrobial susceptibility results

\begin{tabular}{|c|c|c|c|c|c|c|c|c|}
\hline \multirow{2}{*}{ Antimicrobial agents } & \multirow{2}{*}{$\begin{array}{c}\text { Disk } \\
\text { concentrations }\end{array}$} & \multicolumn{2}{|c|}{ Sensitive } & \multicolumn{2}{|c|}{ Intermediate } & \multicolumn{2}{|c|}{ Resistant } & \multirow[b]{2}{*}{$\mathrm{AA}$} \\
\hline & & No. & $\%$ & No. & $\%$ & No. & $\%$ & \\
\hline Enrofloxacin & $5 \mu \mathrm{g}$ & 4 & 40 & 1 & 10 & 5 & 50 & $\mathrm{R}$ \\
\hline Gentamicin & $30 \mu \mathrm{g}$ & 4 & 40 & 1 & 10 & 5 & 50 & $\mathrm{R}$ \\
\hline Co-trimoxazole & $25 \mu \mathrm{g}$ & 5 & 50 & 2 & 20 & 3 & 30 & $\mathrm{~S}$ \\
\hline Amikacin & $30 \mu \mathrm{g}$ & 9 & 90 & 1 & 10 & 0 & 0 & $\mathrm{~S}$ \\
\hline Norfloxacin & $10 \mu \mathrm{g}$ & 3 & 30 & 1 & 10 & 6 & 60 & $\bar{R}$ \\
\hline Doxycycline & $30 \mu \mathrm{g}$ & 3 & 30 & 3 & 30 & 4 & 40 & $\mathrm{~S}$ \\
\hline Levofloxacin & $5 \mu \mathrm{g}$ & 4 & 40 & 0 & 0 & 6 & 60 & $\mathrm{R}$ \\
\hline Tetracycline & $30 \mu \mathrm{g}$ & 3 & 30 & 1 & 10 & 6 & 60 & $\mathrm{R}$ \\
\hline Azithromycin & $15 \mu \mathrm{g}$ & 2 & 20 & 4 & 40 & 4 & 40 & $\mathrm{~S}$ \\
\hline
\end{tabular}

Table 5 PCR for resistance genes

\begin{tabular}{lccc}
\hline Sample & aadB & qnrS & TetA(A) \\
\hline S. Arizonae & + & + & + \\
S. Bananna & + & + & + \\
S. Entritidies & + & + & + \\
S. Kentaky & + & + & + \\
S. Typhimurium & + & + & + \\
\hline
\end{tabular}

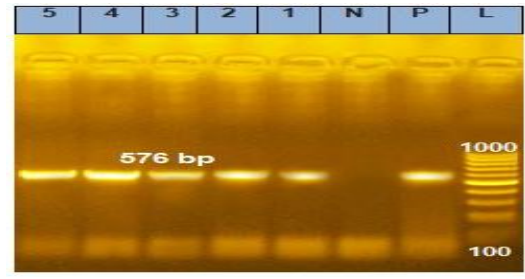

Figure 1 Agarose gel electrophoresis showing specific PCR of Salmonella serotypes using primer set for TetA(A) gene (576bp)- L: ladder. Lane (P): positive control. Lane

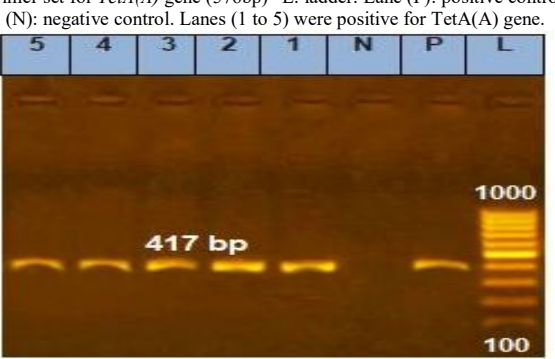

Figure 2 Agarose gel electrophoresis showing specific PCR of Salmonella serotypes using primer set for qnirs gene ( $417 \mathrm{bp}$ )- L: ladder. Lane $(\mathrm{P})$ : positive control. Lane $(\mathrm{N})$ ) negative primer set for qnrs gene (417bp)- L: ladder. Lane (P): p
control. Lanes (1 to 5 ) were positive for TetA(A) gene.

\section{DISCUSSION}

Salmonella is considered one of the most threatened bacterial pathogens to the rabbit industry with health risk impact on human health worldwide. The pathogen causes severe economic losses in poultry farms. Salmonella recently developed multi drug resistant against several antimicrobial agents, which have potential risk on human health as much as the pathogen can infect human (Antoine et al., 2008).

Many previous studies recorded isolation of salmonella species from diseased rabbits as those recorded by Hashem (2020) (detected Salmonella in 56.6\% of the examined rabbit samples) in Egypt; and Camarda et al. (2013) (detected S. Typhimurium in about $20 \%$ of the examined rabbits' organ samples) in Italy. Differences between results may be referred to the difference in environmental conditions, hygienic conditions of rabbitries management, and housing systems.

Animals and human products are commonly infected by a wide variety of Salmonella serovars; one serovar may be a predominant isolate in a country for several years before it is replaced by another serovar. Serovars vary 
geographically, but clinically significant $S$. Typhimurium and $S$. Enteritidis were identified as the most common serovars reported globally (Fsanz, 2005).

The predominant serovars in our study was S. Arizonae, while Elsayed et al. (2017) detected salmonella in $14.07 \%$ of the examined rabbit's organs, where $S$. Typhimurium was detected in $75 \%$ of the examined isolates.

Out of thirty-one Salmonella isolates, ten random isolates were tested for antibiotic sensitivity for (Enrofloxacin, Gentamicin, Co-trimoxazole, Amikacin, Norfloxacin, Doxycycline, Levofloxacin, Tetracycline, and Azithromycin); and found that (60\%) resistant to norfloxacin, levofloxacin, and tetracycline; $(50 \%)$ resistant to enrofloxacin and gentamicin; while most of them were sensitive to co-trimoxazole, amikacin, doxycycline, and azithromycin; which disagreed with (Busani et al., 2004). All the isolates (Salmonella enterica serotypes Typhimurium, Enteritidis, and Infantis isolated from humans, foodstuffs and farm animals in Italy between 1999 and 2001) were susceptible to cefotaxime and ciprofloxacin, but high rates of resistance were observed for several other drugs, especially for S. Typhimurium.

(Randall et al. 2004) found that resistance genes such as aadA1, aphAIAB, cat1, cat2, dhfr $1, \operatorname{str} A, \operatorname{sul} 2$, tetA(A) and tetA(B) were found in a wide range of serotypes with certain. Specificity of some resistance genes to $S$. Typhimurium or non- S. Typhimurium serotypes. These data also indicate that the bla $\left(\mathrm{Carb}_{2}\right)$, floR and tet $\mathrm{A}(\mathrm{G})$ genes reported in the SG1 region of S. Typhimurium DT104, U302 and some other serotypes are still predominantly limited to $S$. Typhimurium strains.

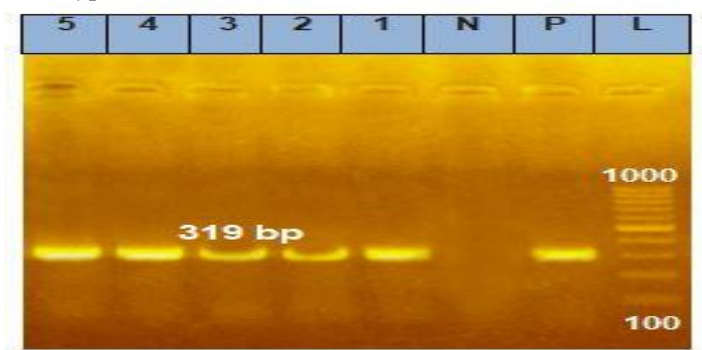

Figure 3 Agarose gel electrophoresis showing specific PCR of Salmonella serotypes using primer set for $a a d B$ gene $(319 b p)$ - L: ladder. Lane (P): positive control. Lane (N): negative control. Lanes (1 to 5) were positive for TetA(A) gene.

Concerning Salmonellae (typhimurium and enteritidis) they were found, specifically in adults. Many studies agreed with these findings and the present results found support from those reported by Joshi and Sardeshpande (1980) who isolated salmonella microorganisms from 37 out 82 rabbits which died during an outbreak of Salmonella typhimurium. Similarly, Palarchi and Belli (1983) and Abd El-Rahman et al. (2005) examined 200 rabbits and isolated Salmonella typhimarium $(5.5 \%)$ and Salmonella enteritidis $(8.2 \%)$. More support was given by the findings reported by ElSayed and Abd El-Latif (2006).

Although uncommon now, salmonellosis was prevalent in the early 1900s. Several authors reported explosive outbreaks of the disease that resulted in the deaths of large numbers of rabbits David (2012). In most cases there was rapid death from septicemia, but diarrhea was occasionally seen as well.

\section{CONCLUSION}

Referring to the obtained results, Salmonellosis is an uncommon disease of rabbits, but it can produce epizootics of high morbidity and mortality. In rabbits, the disease is most often caused by $S$. enterica serotypes Typhimurium or Enteritidis, but other serotypes have been reported. Typhimurium and Enteritidis are also the most common serotypes associated with non-typhoidal salmonellosis in humans (Mandell et al., 2015). Salmonella Arizonae was the most detected in the examined strains; besides, bacteriological and serological routes are still good, reliable method for salmonella detection and identification. Salmonella is highly resistant to streptomycin, Tetracycline and Quinolones antibiotic groups. PCR applied on this resistance genes proved that this group of antibiotics are effective on Salmonella strains.

\section{REFERENCES}

1. Abd El-Rahman, A. A; Neveen, A. H. and Fatma, A. M. (2005): Isolation and pathogenicity of intestinal pathogen associated with enteritis complex in rabbits with especial reference to $E$. coli and Salmonellae. Assuit Vet. Med. J.; 51(106): 180 - 197.

2. Antoine S. T., Annaelle K. and Anne B. (2008): Epidemiological analysis of Salmonella enterica from beef sampled in the slaughterhouse and retailers in Dakar (Senegal) using pulsed-field gel electrophoresis and antibiotic susceptibility testing. J. Food Microbiol. 123: 191-197.

3. Busani, L., Graziani, C., Battiati, A., Attisti, A. and Franco, C. (2004): Antibiotic resistance in Salmonella enterica serotypes Typhimurium, Enteritidis and Infantis from human infections, foodstuffs and farm animals in Italy. Cambridge University.

4. Camarda A, Pupillo A, Pugliese N, Circella E, Dionisi AM, Ricci A, Pazzani C. (2013): Phenotypic and genetic traits of Salmonella enterica subsp. serovar Typhimurium strains causing salmonellosis foci in rabbit farms from Southern Italy in 19992003. Research in Veterinary Science, 94(3): 394398.

5. Camarda, A., Pupillo, A., Pugliese, N., Circella, E., Dionisi, A., Ricci, A. and Pazzani, CDC (Centers for Disease Control and Prevention), (2015): Salmonella Infection.

6. $\mathrm{CDC}$ (Centers for Disease Control and Prevention), 2018. Steps in a Foodborne Outbreak Investigation.

7. EL-Sayed, H. M. and Abd El-Latif, M. M. (2006): Studies on some Bacteria associated with abortion in rabbits. Assuit Vet. Med. J. 52 (109) 285-290.

8. Elsayed, M.E., Ammar, A.M., Mohamed, A.E. and El-Demerdash, A.S., (2017): Bacteriological Survey on Salmonella Enterica from Rabbit and Poultry with Special Reference to Its Antibiotic Resistance Patterns. SCVMJ, 22(2): 9-18.

9. Frana, T. S., Carlson, S. A. and Griffith, R. W. (2001): Relative distribution and conservation of genes encoding aminoglycoside-modifying enzymes in Salmonella enterica serotype Typhimurium phage type DT104. Applied and Environmental Microbiology 67, 445-448.

10. FSANZ "Scientific assessment of the public health and safety of poultry meat in Australia. Food 
Standards Australia New Zealand", 2005. $3^{\text {rd }}$ attachment.

11. Gal-Mor O, Boyle EC, Grassl GA (2014): Same species, different diseases: how and why typhoidal and non-typhoidal Salmonella enterica serovars differ. Frontiers in Microbiology. 5: 391.

12. Hashem, S.M., (2020): Some parasitic, bacterial and husbandry causes of mortality in rabbits during suckling and growing stages and trials to improve their health condition. Thesis, Master of Veterinary Medicine (Parasitology Dept), Beni- Suef Univ., Egypt.

13. ISO "International Organization for Standardization", (2017): International Organization for Standardization. No.6579-1. Microbiology of the food chain Horizontal method for the detection, enumeration and serotyping of Salmonella -Part1.

14. Joshi, A. P. And Sardeshpande, P.D. (1980): Observation on Salmonellosis in Guinea pigs and rabbits. Indian Vet. J., 27 (11):882- 884.

15. Mandell, Douglas, and Bennett's Principles and Practice of Infectious Diseases (2015): Salmonellosis associated with exotic pets is a resurgent public health Problem, especially from exposure to reptiles, including turtles, iguanas, frogs, lizards and snakes.

16. Markey, B.K., Leonard, F.C., Archambault, M., Cullinane, A. and Maguire, D. (2013): Clinical Veterinary Microbiology. Second edition. MOSBY. Elsevier Ltd.

17. Michael P.; O'Dwyer, Jean; Adley, Catherine C. (2017): "Evaluation of the Complex Nomenclature of the Clinically and Veterinary Significant Pathogen Salmonella". BioMed Research International. 2017: $1-6$.

18. Mondal, T., Khan M. S. R., Alam M. and Purakayastha, M. (2008a): Molecular Characterization of Salmonella Isolates of Duck in Comparison to Salmonella Isolates of Chicken and Ruminants. Bangladesh J. Microbiology, 25(2): 9194.

19. Okoro CK, Kingsley RA, Connor TR, Harris SR, Parry CM, Al-Mashhadani MN, Kariuki S, Msefula CL, Gordon MA, de Pinna E, Wain J, Heyderman RS, Obaro S, Alonso PL, Mandomando I, MacLennan CA, Tapia MD, Levine MM, Tennant SM, Parkhill J, Dougan G. ( 2012): Intracontinental spread of human invasive Salmonella Typhimurium pathovariants in sub-Saharan Africa. Nature Genetics. 44 (11): 1215-21.

20. Palarchi, M. and Belli, A. (1983): Testing animal and food products for Salmonella in the Province Florence in 1979 to 1981.Giornale di Malattie Infective parasitarie, 35 (8):905- 907.

21. Panda, A., Tatarov, I., Masek, B., Hardick, J., Crusan, A., Wakefield, T., Carroll, K., Yang, S., Hsieh, Y., Lipsky, M., McLeod, C., Levine, M., Rothman, R., Gaydos, C.A. and DeTolla, L.J. (2015): A rabbit model of non-typhoidal Salmonella bacteremia. Comp. Immunol. Microbiol. Infect. Dis., 37(4): 211-220.

22. Randall, L.P.; Cooles, S.W.; Osborn, M.K.; Piddock, L.J.V. and Woodward, M.J. (2004): Antibiotic resistance genes, integrons and multiple antibiotic resistance in thirty-five serotypes of Salmonella enterica isolated from humans and animals in the
UK. Journal of Antimicrobial Chemotherapy. 53, 208-216.

23. Robicsek, A.; Strahilevitz, J.; Jacoby, G.A.; Macielag, M.; Abbanat, D.; Park, C.H.; Bush, K. and Hooper, D.C. (2006): Fluoroquinolone modifying enzyme: a new adaptation of a common aminoglycoside acetyltransferase. Nat Med 12:8388.

24. Saco M.1, Pérez de Rozas A., Aloy N., González J., Rosell J.M. Badiola J.I. (2012): Salmonellosis in rabbits. Field and laboratory Results during 19992011. 10 th World Rabbit Congress - September 3 6, 2012- Sharm El- Sheikh -Egypt, 1165- 1168.

25. Sambrook, J.; Fritscgh, E.F.; and Mentiates (1989): Molecular cloning. A laboratory manual. Vol 1., Cold spring Harbor Laboratory press, New York.

26. Zahraei T, Mahzouniehand M and Khaksar E (2010): Detection of Salmonella serovars in zoo and pet reptiles, rabbits, and rodents in Iran by culture and PCR methods. 